\title{
Problems of Sustainable Functioning of Urban Transport Systems
}

\author{
Tatyana Konovalova ${ }^{1}$, Irina Kotenkova ${ }^{1 *}$, and Ivan Senin $^{1}$ \\ ${ }^{1}$ Kuban state technological university, 2 Moskovskaya str., Krasnodar, 350072, Russia
}

\begin{abstract}
The main problems of transport systems in big cities have been analyzed, the problems of transport functioning, their division into groups have been systematized, the highway structure of the constituent entities of Russian Federation has been analyzed, the issues of the development and maintenance of the urban highways have been considered, the problems of existing urban areas, as well as the problems of transport systems designing have been considered, and the main directions of the current situation solution have been suggested.
\end{abstract}

\section{Introduction}

The transport systems problems are especially acute for residents of big cities every day. Difficulties with the movement on off-road automobile network are less noticeable and they occur periodically in the "hot time" (the period of holidays) and to directions which are connected with the high vehicles concentration. These and other troubles indicate the problems of different levels. In the first case, this is a list of issues related to the high population concentration, accordingly, to the formation and management of the city's transport system, in the second case, the "peak of vehicles' load in time and space and, accordingly, issues related to the creation, development and operation of the country's, regions' and districts' transport system.

\section{Material and methods}

Nevertheless, the main problems of the transport systems' functioning are unified for all cases. They can be systematized and divided into three large groups: economic, managerial and dependent [1].

Economic:

- motorization's level increase;

- increase of the intensity of individual transport usage;

- increase in city residents' need in travelling.

Managerial:

- imperfection of the system of organization and management of the development of the road transport complex;

* Corresponding author: ir-kot83@mail.ru 
- urban planning and planning problems of territorial and urban development;

- imperfect legislative base at the federal, local and regional levels in the field of transport system management.

Dependent:

- disproportion between the motorization level and the road construction rates;

- urban passenger transport efficiency decrease;

- insufficient information component when making managerial decisions;

- financing gaps of the road networks and transport infrastructure development;

- unsettledness of property issues and the issues of delineation of property rights and management of transport infrastructure facilities.

Some explanations will be given for third group, which will allow us understand its title and the assignment of problematic issues to this category. These problems are dependent with regard to the first and second categories and, accordingly, follow from them. For example, the problem with the lack of financing for the development of road networks and transport infrastructure is economic, at first sight, but, in our opinion, is dependent on an imperfect legislative framework, organization and management of the development of the road transport complex. This problem is closely connected with the unresolved property issues concerning to the delineation of property rights and the transport infrastructure management [2].

\section{Theory}

The existing legislative acts abound with a large number of shortcomings and omissions, as well as the lack of a clear powers delineation between the federal, regional and local government levels.

In accordance with the responsibilities and funds distribution between the government levels, the responsibility of the municipality is to develop and maintain a network of urban highways [3]. The municipality accounts for more than $70 \%$ of the length of public roads (table 1).

At the same time, the local budget receives no more than $10 \%$ of all taxes and fees (table 2).

The length of motor roads in the territory of the Rostov Region and the Krasnodar Territory, broken down by belonging, is presented in table 1 .

Table 1. Structure of highways of the Russian Federation subjects.

\begin{tabular}{|c|c|c|c|c|c|c|c|c|}
\hline The & \multirow{2}{*}{$\begin{array}{c}\text { The public } \\
\text { Federation } \\
\text { subject } \\
\text { title }\end{array}$} & $\begin{array}{c}\text { highway's } \\
\text { length }(\mathbf{k m}) \\
\text { totally }\end{array}$ & \multicolumn{2}{|c|}{ Federal } & \multicolumn{2}{|c|}{$\begin{array}{c}\text { Regional and } \\
\text { intermunicipal }\end{array}$} & \multicolumn{2}{|c|}{ Municipal } \\
\cline { 5 - 9 } & & & & & & & \\
\hline $\begin{array}{c}\text { The } \\
\text { Trasnodar } \\
\text { Territory }\end{array}$ & 39627 & $100 \%$ & 1310 & $3,3 \%$ & 10210 & $25,8 \%$ & 28107 & $70,9 \%$ \\
\hline $\begin{array}{c}\text { The Rostov } \\
\text { Region }\end{array}$ & 35359 & $100 \%$ & 716 & $2,0 \%$ & 7533 & $21,3 \%$ & 27110 & $76,7 \%$ \\
\hline
\end{tabular}

On the other hand, inefficient management, lack of understanding of the importance of infrastructure development issues (including the road network) - as a locomotive of the economy, leads to significant economic losses. The annual amount of losses and lost profits only associated with the deficiencies of the country's road network is estimated by experts at $450-500$ billion rubles. 
Table 2. Tax, fee and other mandatory payments' revenues to consolidated budget of the Russian Federation (million rubles).

\begin{tabular}{|c|c|c|c|c|c|c|c|c|}
\hline $\begin{array}{c}\text { Taxes, fees, other } \\
\text { mandatory payments } \\
\text { received as income, } \\
\text { including: }\end{array}$ & $\mathbf{2 0 1 2}$ & $\mathbf{\%}$ & $\mathbf{2 0 1 3}$ & $\mathbf{\%}$ & $\mathbf{2 0 1 4}$ & $\mathbf{\%}$ & $\mathbf{2 0 1 5}$ & $\mathbf{\%}$ \\
\hline Federal budget & 2502,596 & 35,7 & 3174,307 & 37,6 & 4480,464 & 42,4 & 4843,058 & 43,5 \\
\hline $\begin{array}{c}\text { Consolidated budget of the } \\
\text { constituent entities of the } \\
\text { Russian Federation }\end{array}$ & 3785,699 & 54,1 & 4488,587 & 53,2 & 5239,135 & 49,5 & 5367,318 & 48,2 \\
\hline The local budjet incomes & 714,096 & 10,2 & 781,984 & 9,2 & 854,391 & 8,1 & 921,850 & 8,3 \\
\hline
\end{tabular}

The road network has been formed in the middle of last century and since that it has not undergone any significant changes [4]. Last years, the road network development rate has lagged significantly behind the economic growth rates and the country's motorization paces. At the car fleet growth by $3-7 \%$ per year, depending on the region, the throughput of Russian roads annually increases less than $1 \%$.

The problem of underfunding is more appreciable in municipalities. The problems listed above are more acute in large cities due to population concentration, the building density, higher wages, etc [5].

At the same time, the local budget receives no more than $10 \%$ of all taxes and fees (table 2).

The main problem of the existing urban areas in present-day Russia, taking into account the pace of the population motorization, is the overload of both the street-road network and its individual nodes, the lack of parking spaces both at the places of employment and in the places of residence and, as a consequence, the deterioration of the ecological situation [6].

\section{Results and discussion}

Thus, the imbalance of the transport network development with the opportunities which are provided to population and legal entities in terms of transportation facilities providing are clearly visible. The imbalance problem can be broken down into the following components [7]:

- disproportion in the dynamics of the various means of transport development, both as for urban transport so for long-distance and international transportation. The road transport is developing with accelerating paces displacing rail and water transport inside the cities and aviation at inter urban passenger transportation;

- insufficient development of transport infrastructure of highways in relation to the level of motorization and road transport demand ;

- problems at the "junctions" of various means of transport. As a rule, the infrastructure development of various means of transport is carried out independently of each other, and sometimes on the basis of competition for unoccupied territories and engineering infrastructure. Technologically different means of transport exist separately without taking into account the features of the technological process [8];

- territorial irregularity of transport infrastructure development. These differences are observed both in the urban area and in areas free from buildings [9];

- the problems of the territory planning organization, connecting with the lack of accounting of urban development dynamics, as from the point of view of the development of its separate elements (residential areas, zones of cultural and domestic attraction, places of employment, including both industrial objects, big business centers, administrative institutions or a dense concentration of small objects in a certain territory), their mutual 
linking, and taking into account the city development prospects as an integral entity with the development of new territories [10].

The imbalance of urban development is most sharply manifested in conditions of dynamic growth that has been observed for the last 5-10 years. The basis for the municipality development, in these conditions, is the predominance of individual interests over public, the attraction of non-public investment by any means and all this is supported by the high level of corruption and incompetence of officials - decision makers. Therefore, for the urban areas development with their transport support - as a basis for "close relations" and places of employment - as an economic platform for their existence, it is necessary to have a clear, stage-by-stage planning of the transport component, primarily, taking into account the places of origin and merger of passenger and cargo flows. It's necessary to refer to such places not only industrial areas which have very differentiated specificity of location and development, mutual influence, interaction with residential development [11]. Finally, they can impede the city development and demand their removal from its already central part or dense residential development. But it is necessary to take into account big malls, sports complexes and business centers, which, at the same time, have their own technological processes, unevenness in attracting of passenger and cargo flows. Thus, the formation of cities separately and also agglomerations as a whole, in general should be carried out based on the balanced allocation of places of traffic flows attraction and the possibility of organizing and developing of transport communications. All means of transport attracting is necessary for implementation of the transportation process, primarily road, rail means of transport, but we must not forget about water transport, which, with considering its seasonality, can provide recreational, cultural and tourist connections. The places of employment must be located not only from the point of view of intrurban movements, it is necessary to take into account suburban communications within the agglomeration. It must considered that the transport infrastructure development on undeveloped territory, becomes the center for business attracting and developing, production facilities, in turn, the location of large production facilities like "anchor ones", makes it necessary to take into account the territorial development of auxiliary and other subjects which gravitate toward the developed engineering and transport infrastructure [12]. Today, we need the forecasted and balanced development of places of residence and employment providing engineering infrastructure, transport communications, which should take into account, cultural, social and other links, with minimum delays during «peak hours» and the possibility of reconstruction in case of development of territories falling within in their service area.

Currently, as it was already pointed out above, in big cities, taking into account their dynamic development, there is a tendency of industrial buildings removal beyond urban boundaries. Or, in another way, it can be formulated as a problem of changing of the city planning organization. This situation has developed by several reasons, which include [13]:

- formation of urban development in the pre-revolutionary period and in the Soviet era. This circumstance did not take into account the prospect of mass use of personal vehicles, high-rise buildings, high concentration of places of residence and places of employment. The car is in irreconcilable conflict with the old cities layout and the common planning traditions;

- resettlement structure's change with a dynamically growing share of the urban population;

- imperfection of the norms of territorial planning and town planning concerning the transport system development;

- predominance of the intuitive overlay of transport services network built on the nonconnected with transport grounds of a city plan; 
- lack of computational and theoretical methods of designing of the intracity transport network. It can be said that, the street-road network of the city is not designed, but drawn;

- expansion of the city boundaries. It is typical and relevant for big cities, due to a constant population influx, it is a consequence of higher wages and a greater probability of employment;

- large environmental load from production facilities located in the city and from transport, which supplies raw materials and components and carries out the export of finished products;

- change in land resources cost, due to the change in the boundaries of the central part of the city.

The above problems, in our opinion, are basically the attempts to form and put the problem in terms of the cause, not the consequence. As a rule, the design of urban transport systems is aimed to solve existing problems, which have already arisen as a result of life activity. When designing transport systems, as a rule, the axes and technical parameters of the road network have already been formed, red lines, lines of construction, parameters of capital construction objects, places for recreation and entertainment, etc. have been determined. In such conditions, the design of the transport system is led to determining current situation, the examining of existing correspondence between the elements of the city planning [14].

The main problems of designing transport systems at this stage are [15]:

- Development of methods for correspondence passenger's survey;

- Analysis and compilation of information on the survey of passenger flows, determination of the patterns of their movement;

- Development of technique for passenger flows forecasting in conditions of big cities development;

- Identification of bottlenecks and shortcomings of the existing transport scheme, determination of main directions for its adjustment;

- Determination of evaluation criteria for the projected indexes of passenger flows;

- Determination of share movements with usage of personal motor transport;

- Justification of the use of street or high-speed (street) extracurricular transport;

- Formation of a system of intra-urban multimodal transport with the use of «park and ride» technology;

- Determining of transport-transfer nodes parameters;

- Identification of the parameters and infrastructure of individual non-mechanical ecological transport modes (bicycle, Segway) and development of measures to encourage their use;

- Principles for the creation of non-transport zones in the central regions of the big cities;

- Forming principles of the of places of permanent and temporary storage of cars (in places of residence, at places of employment and during mass events, at multimodal sites);

- Development of measures for the interaction of various types of passenger transport (street, off-street, high-speed, electric, public, individual, etc.);

- Forming principles of urban high-speed roads, including chordal highways;

- Determination of direction and volume of freight flows in the city;

- Determination of parameters and influence zone of capital construction objects on the loading of the street-road network.

Thus, the main problem of design is the lack of methods, criteria for estimating parameters, assessing the state of urban transport systems and public services, and allowing predict the state of the system. 


\section{Conclusion}

As it can be seen from the above-mentioned problems of the development and operation of city transport systems, their list is quite broad, and perhaps not fully presented. The issues of organization and management of traffic, as well as problems and development of measures to improve road safety, etc. are not considered.

For a well-functioning urban transport system, we need a solution for three, interrelated groups of tasks in the field of research for determining the parameters of urban transport system performance indicators, the second group is design, construction and their legal and regulatory support, and finally, the organization of their functioning.

\section{References}

1. T.V. Konovalova, I.N. Kotenkova, Transport infrastructure: tutorial. Ed. FGBOU VPO "KubGTU", Krasnodar, P. 264 (2013)

2. T.V. Konovalova, I.N. Kotenkova, M.D. Bulanova, A.I. Parnevaya, On the issue of optimization of traffic flows on the street-road network of big cities (on the example of Krasnodar). In the collection: Perspectives of development and safety of the motor transport complex Materials of the IV International Scientific and Practical Conference. Responsible editor S.I. Klimashin, pp. 158-161 (2014)

3. T.V. Konovalova, I.N. Kotenkova, D.V. Kolomiytseva, Problems of transport planning of territories. Road transport of the Far East, 1, pp. 025-028 (2013)

4. I.N. Kotenkova, T.V. Konovalova, M.V. Kotenkov, Optimization of the functioning of the city transport system. In the collection: Problems of the road and road complex in Russia: Organization of road transport and road safety Materials of the VII International Correspondence Scientific and Technical Conference (2013)

5. T.V. Konovalova, I.N. Kotenkova, L.S. Zarovnaya, Investments efficiency in the regional road facilities. In the collection: Problems of the automobile and road complex in Russia: Organization of road transport and road safety. Materials of the VII International Correspondence Scientific and Technical Conference. Managing editor: E.R. Domke, pp. 136-142 (2012)

6. T.V. Konovalova, I.S. Senin, Concideration of regional features at optimizing of binding networks of highways. In the collection: Problems of the automobile and road complex in Russia: Organization of road transport and road safety Materials of the VII International Correspondence Scientific and Technical Conference. Managing editor: E.R. Domke, pp. 58-64 (2012)

7. T.V. Konovalova, I.N. Kotenkova, Traffic safety as a subsystem of the transport and logistics system in the region. Bulletin of the Saratov State Technical University, 2 (71), pp. 275-279 (2013)

8. L.N. Vorobyova, A.I. Seslavin, Gradient method for the centralized management of urban transport systems. Science and technology of transport, 2, pp. 71-73 (2005)

9. K.N. Isakov, V.Ya. Builenko, Main directions of organization management of urban transport systems. In the world of scientific discoveries, 2.6 (26), pp. 130-137 (2012)

10. N. A. Muraviev, I.S. Nikolaev, M.H. Kabaev, Analysis of the problems of management of urban transport systems. Scientific-methodical electronic journal Concept, 35, pp. 86-90 (2015) 
11. I. E. Agureev, W.A. Lush, L.E. Kushchenko, I.A. Novikov, A.G. Shevtsova, The problems of management of urban transport systems. Contemporary socio-economic processes: problems, patterns, prospects. Penza, pp. 72-94 (2017)

12. G.V. Savin, Methodical approach to development of urban transportation system based on the balanced scorecard. Regional economy and management: electronic scientific journal, 4 (48), pp. 470-479 (2016)

13. V.V. Donchenko, Yu.I. Kunin, D.M. Kazmin, V.V. Mekhonoshin, Problems of sustainable development of urban transport systems in the Russian Federation. Transport: Nauka, Tekhnika, Upravlenie, 7, pp. 38-46 (2008)

14. RAO Amudapuram Mohan, RAO K.Ramachandra, Identification of traffic congestion on urban arterials for heterogeneous traffic. Transport Problem. Politechnika Slaska, 3 (11), pp. 131-142 (2016)

15. M. Krasnyanskiy, N. Penshin, Qualily criteria when assessing competitiveness in road transport services. Transport Problem. Politechnika Slaska, 4 (11), pp. 15-20 (2016) 